\title{
Robotic milking of dairy cows: a review
}

\section{Ordenha robotizada de vacas leiteiras: uma revisão}

\author{
Luiz Marcos Simões Filho ${ }^{1}$; Marcos Aurélio Lopes ${ }^{2 *}$; Sergio Corrêa Brito ${ }^{3}$; \\ Giuseppe Rossi ${ }^{4}$; Leonardo Conti ${ }^{4}$; Matteo Barbari ${ }^{4}$
}

\section{Highlights:}

Addressed the history, operation, advantages and limitations of use.

Advantages: reduction of labor and the potential to improve feed conversion.

Advantages: improves quality (reduced CCS) and increases cow productivity.

Advantages: provides data and parameters for a more adequate management of the activity.

Main limitations: high investment value and changes in milk solids.

\begin{abstract}
Automatic milking systems (AMS) have aroused worldwide interest recently. The first installation was by the company Lely in a project in the Netherlands (its homeland) in 1992. But nowadays, AMS represents a growing reality due to lobby for labor issues, rising costs, difficulty finding well-trained workers, and/ or difficulty keeping people on farms. This work aimed to present a review of the literature on AMS, beginning with a brief history of the evolution of the technology, showing advantages and limitations of its use, and ultimately giving some suggestions. The understanding of the technical functioning and operational running can help farmers and technicians in decision making on the adoption of the new technology. Besides workforce reduction and labor quality promotion, AMS has potential to improve feed conversion to milk, milk quality (with lower SCC), and cow productivity, as well as providing useful data and parameters for better farm management. Potential limitations include high investment costs, changes in milk composition (solids, free fatty acids), and increased risk of ketosis in cows.
\end{abstract}

Key words: Automation. Dairy cattle. Milking robot. Precision livestock farming.

\section{Resumo}

Robôs ordenhadores são uma novidade razoavelmente recente no mundo. O primeiro foi instalado em 1992, pela empresa Lely, em um projeto experimental em seu país de origem, a Holanda. Entretanto, trata-se de uma realidade presente e cada vez maior, pois o problema da mão de obra, em diversos locais do mundo, cada vez mais cara, pouco capacitada e/ou difícil de manter na fazenda, é inexorável. Objetivou-se apresentar uma revisão da literatura sobre a utilização da robótica na ordenha de vacas leiteiras, abordando o funcionamento técnico e operacional, bem como vantagens e limitações de sua utilização, visando auxiliar pecuaristas e técnicos na tomada de decisões em adotar, ou não, essa tecnologia. Apresentou-se, ainda, um breve histórico da evolução dos robôs ordenhadores, bem como

1 Discente de Mestrado, Universidade Federal de Lavras, UFLA, Departamento de Medicina Veterinária. Lavras, MG, Brasil. E-mail: msimoes1979@icloud.com

2 Prof., Titular, UFLA, Departamento de Medicina Veterinária. Lavras, MG, Brasil. E-mail: malopes@dmv.ufla.br

3 Médico Veterinário, Gerente de Grandes Projetos, DeLaval, Jaguariúna, SP, Brasil. E-mail: sergio.brito@delaval.com

4 Profs., Università degli Studi di Firenze, Firenze, Italy. E-mail: giuseppe.rossi@unifi.it; leonardo.conti@unifi.it; matteo.barbari@ unifi.it

* Author for correspondence 
algumas considerações finais. Constatou-se que os robôs, além de substituírem mão de obra, possuem o potencial de melhorarem a conversão alimentar para leite, a qualidade do leite (baixar CCS), aumentar a produtividade das vacas e proporcionar dados e parâmetros para uma gestão mais adequada dos números da atividade dentro da fazenda. Dentre as possíveis limitações estão o alto valor de investimento, alterações em sólidos do leite, presença de ácidos graxos livres no leite e aumento nos riscos de cetose nas vacas.

Palavras-chave: Automação. Bovinocultura leiteira. Robô ordenhador. Zootecnia de precisão.

\section{Introduction}

Efforts to increase and improve milk yield is a challenge that is mainly in the hands of farmers. It all starts on the farm, and dairy farmers have at the top of the priority scale, among other key points, the focus on cost reduction. According to the Empresa Brasileira de Pesquisa Agropecuária [EMBRAPA] (2018), the production cost of dairy farming is an important bottleneck and requires in-depth studies to be reduced to its maximum. However, the quality of the final product (fundamental for international competitiveness), and a good working environment must be guarded, besides avoiding environmental impacts.

Mechanization of operations is an impactful way to reduce costs in farming activities, in addition to automating certain processes using milking robots or automatic milking systems (AMS). Although the first commercial systems emerged in 1992, they have been adopted at an increasing rate in many countries (Bach \& Cabrera, 2017). This form of cost reduction can allow important savings, especially in labor matter, which, according to Santos and Lopes (2012) and Silva et al. (2019), may represent reductions of about 15.81 and $15.24 \%$, respectively, on effective operating cost. Labor may represent one of the main sources of monthly spending on a farm, second only to livestock feed (Lopes et al., 2015, 2016; Ferrazza, Lopes, Bruhn, Moraes, \& Carvalho, 2017; Villela et al., 2017; Moraes et al., 2018; Santos, Almeida, \& Lopes, 2018).

According to Tse, Barkema, De Vries, Rushen and Pajor (2017, 2018a), milking using AMS can provide a series of tangible and intangible benefits to farms. Cost reduction can be achieved while ensuring main conditions for any commercial activity, such as quality of the final product and working environment, as well as environmental preservation.

The question to be answered is to what extent milking robotization could help improve and increase milk production. Examples would be: a) production costs are reduced as milk productivity increases (Endres \& Salfer, 2015); and b) product sanitary quality is improved as somatic cell count decreases due to a higher frequency of milking (Hale, Capuco, \& Erdman, 2003; Dahl, Wallace, Shanks and Lueking, 2004; Eslamizad, DehghanBanadaky, Rezayazdi and Moradi-Shahrbabak, 2010).

Reports of AMS manufacturers indicate inexorable growth in sales worldwide in recent years, with about 50,000 AMS already in operation, a number that has increased strongly every year.

Given the above, this work aimed to present a review of the literature on AMS, with a brief history of the evolution of the technology, showing advantages and limitations of its use, and finally giving some suggestions. The understanding of the technical functioning and operational running can help farmers and technicians in decision making on the adoption of the new technology.

\section{AMS operating}

To better understand AMS, it must be analyzed in a different way than conventional milking. Its basic premise is that cows must be milked voluntarily 
with no human presence, at any milking stage. Therefore, the animals must enter the milking box without being herd.

Currently, around the world, AMS is, in most cases, operating in free-stall or compost barns. However, according to Lyons, Kerrisk and Garcia (2013), in 2001, AMS was first incorporated into pasture-based systems, with installations being placed in commercial farms in Australia and New Zealand almost simultaneously. A broad literature review was published by Lyons et al. (2014), summarizing information on AMS use in pasturebased systems. Furthermore, this technology has been used in pasture-based systems in Australia (Wildridge et al., 2018; John et al., 2019), Ireland (Shortall, Foley, Sleator, \& O’brien, 2018a; Shortall, O'brien, Sleator, \& Upton, 2018b), and the United States of America (Nieman, Steensma, Rowntree, Beede, \& Utsumi, 2015). It is noteworthy that pasture and mixed systems (semi-confinement with grazing) have already become a reality in Latin America in projects in Argentina and Chile since 2015. In Brazil, a pasture system has been developed in the state of Rio Grande do Sul.

According to Hogeveen, Ouweltjes, De Koning and Stelwagen (2001a) and Hogeveen, Vandervorst, De Koning and Slaghuis (2001b), AMS systems are composed of the following parts: containment system, a sensor system for teat detection, a robotic arm for insufflator attachment, teat cleaning system, software and the milking equipment itself. Paiva, Pereira, Tomich and Possas (2015) reported that access control by smart gates (one or more) and individual electronic identification (usually a collar) determine the paths the cows should take to access the AMS unit or the feeding alley.

According to Maculan and Lopes (2016), an AMS consists of a mechanical arm that performs several functions in the milking process. After cow electronic identification, the system checks the time of the last milking and directs the animal through as the system was parameterized. If the cow is to be milked, it enters the AMS box, where concentrate feeding is released and the mechanical arm begins its work. The steps are as follows: a) detecting udder and teats; b) teat cleaning by water and air jets, or rollers; c) pre-dipping; d) attachment of teat cups for milking; e) individual detachment of teat cups as milk flow decreases to avoid over-milking; f) post-dipping using a spray. It is important to note that not all AMS models perform the routine aforementioned. For example, some models do not perform pre-dipping only teat cleaning. Another feature that is not common to all models is individual removal of teat cups as soon as milk flow reduces. Some models consider full milk flow to remove the four teat cups at the same time, just as in conventional milking where automatic extractors are used.

Milking permission is defined per cow according to lactation stage and expected milk yield. Thus, different animal-flow models can be used in a voluntary milking system. The first and simplest is classified as free flow, where cows have free access to milking station, resting area, and feeding alley. Animal herding patterns were also developed to improve system efficiency, increase the number of milking visits, and reduce the number of cows to be herded into the AMS, as they do not go themselves voluntarily. The first one is the 'feed first' system, which is based on free access of cows from the resting area to the feeding area. But to return to the resting area, cows must pass through a selection gate, from where animals with milking permission are directed to the milking waiting room. Cows that cannot be milked return to the resting area, while only cows that have to be milked reach the AMS. Another applicable system is 'milk first', in which cows must pass through a selection gate to access the feeding alley. From this area, cows with milking permission are directed to the AMS; only after that, they have free access back to the resting area.

For AMS milking, complete planning is designed for each animal based on its lactation stage and productive potential. In this system, the 
main fixed parameters are number of milking events per day, amount of concentrate feed to be offered in AMS box per visit, type of feed to be supplied. Concentrate feed acts as a lure to attract cows into the AMS box. The feed is added to a trough that receives it from a vacuum pump or endless screw system. A new technology, already designed and installed in some farms, has allowed the supply of up to four different concentrate feeds. This system identifies each cow electronically, providing it specific feed in a previously defined quantity.

Depending on the type of system (free-flow or guided), feed supplied inside the robot must be more or less attractive to enable as many visits as possible to the AMS (Jacobs \& Siegford, 2012a). Several researchers (Halachmi, Ofir, \& Miron, 2005; Migliorati, Speroni, Lolli, \& Calza, 2005; Bach, Dinarés, Devant \& Carré, 2007; Trembley et al., 2016; Hare, De Vries, Schwartkopf-Genswein, \& Penner, 2018) have stated that the concentrate provided in guided-flow systems does not increase animal motivation to enter the AMS. Menajovsky et al. (2018) found that higher amounts of concentrate in AMS (about $6 \mathrm{~kg} \mathrm{day}^{-1}$ ) increased milk yield per cows but did not affect the frequency of milking visits.

In practice, the goal is to reach, at the end of a defined period (day or month), the highest average milk yield per AMS possible. Companies have reported numbers that range from 2,500 to 3,000 L per AMS a day, which depends on several issues such as animal breed; however, in some reports, these figures are even higher.

According to Endres and Salfer (2015), to reach the highest milk yield per AMS a day, two points must be sought: 1) introduce high-production cows into the herd and provide good nutritional management; 2) reduce box occupancy time (i.e., high milk flow in $\mathrm{kg} \mathrm{min}{ }^{-1}$ per milking visit, up to $3.5 \mathrm{~kg} \mathrm{~min}^{-1}$ ). Endres and Salfer (2015) suggested that, in case of herds of high genetic value, a suitable number of cows should be estimated to optimize times of milking per cow a day, occupying the AMS box for the shortest time possible. The goal is to ensure maximum values in terms of total milking visits and milk production per robot a day. Another way to raise efficiency and productivity is to only allow access to the robot for cows to be milked. What is possible by pre-selection gates, which are common in guided animal flow systems.

Although the frequency of milking per day in AMS can be increased by parameterizing the system to allow cows to be milked more times daily. Dzidic, Macuhova and Bruckmaier (2004) and Melin, Svennersten-Sjaunja and Wiktorsson (2005) reported that it is not very realistic to expect more than three milking visits per cow a day on average.

\section{Flow systems: free and guided}

An intense discussion in both academic and manufacturing spheres regards the best flow system to be used in an AMS. Many questions are still open, among them is which of the systems is the most comfortable for cows or for farmers. Some details concerning the functioning of both systems and their main advantages and limitations are here reported.

Basically, three types of animal flows can be adopted in an AMS: free flow, feed first (guided flow with feed supply first), milk first (guided flow with milking first).

\section{Free-flow system}

In free-flow system, cows have unrestricted access to any area, that is, there are no access gates anywhere but in the AMS entrance; therefore, cows are free to access any location at any time. Bach, Devant, Igleasias and Ferrer (2009) stated that the number of AMS visits was lower when cows were kept in a free-flow system than in a guided-flow system. Ketelaar-de Lauwere, Hendriks, Metz and Schouten (1998) found a similar trend. Bach et al. 
(2009) found that cows kept in a free-flow system were unintentionally conducted to milking 0.5 times a day, whereas cows kept in a guided-flow system were conducted only 0.1 times a day. Melin, Pettersson, Svennersten-Sjaunja and Wiktorsson (2007) pointed out that a free-flow system provides greater animal welfare and suitable feed intake, with cows consuming greater dry matter content than in a guided-flow one. Furthermore, a more precise diet formulation to meet specific animal demands can be provided by such a system. Thune (2000) showed that free-flow systems promote fewer cow lines, thus less time waiting, and less interaction between dominant and subordinate cows.

\section{Guided-flow systems (feed first and milk first)}

As mentioned before, there are two types of guided-flow systems, 'feed first' and 'milk first'. In the feed first, cows have access to the feeding alley, and through selection gates and drivers, they are forced to reach the AMS box so they could return to the resting area. In turn, the opposite happens in the milk first, wherein cows must pass through the AMS box first to then access to the feeding alley and return to the resting area.

Both systems have similar advantages and limitations. Bach et al. (2009) demonstrated that a guided-flow system leads to lower total dry matter intake, cow eating time, and daily meals. Ketelaarde Lauwere et al. (2000), Harms, Wendl and Schon (2002) and Melin et al. (2007) reported similar results. Bach et al. (2009) added that drastic changes in natural eating behavior may lead to ruminal acidosis. It happens because cows reduce feed consumption significantly in guided-flow systems, and tend to eat more when feed is available (feeding alley). Rumen acidosis can lead to reductions in milk fat. Bach et al. (2009) also reported a possible decrease in milk protein rates in guided-flow systems as a function of the potential decrease in dry matter consumption.
Thune (2000) stated that guided-flow systems result in long queues for entry to the AMS, which can lead to serious hoof and welfare problems, especially in animals with more submissive behavior.

As reported by some researchers (Ketelaar-de Lauwere et al., 1998; Bach et al., 2009), a major gain from a guided-flow system is a significant reduction in the number of the so-called fetch cows, i.e., cows that do not visit the AMS voluntarily or do not adapt to the system (often cows with longer lactation days).

De Vries, Von Keyserlingk and Beauchemin (2005) claimed that the major challenge in a guidedflow system is to encourage more movement of cows within the barn so that they can enter the AMS more often. This goal can be achieved by offering a greater amount of meals per day, thus generating more movement, greater dry matter intake, longer times in feeding area and, hence, more visits to the AMS. According to these authors, this trend can also be observed in a free-flow system.

\section{A brief history of different generations of AMS}

AMS manufacturers and suppliers are constantly upgrading their systems to always present something new to the market, both in terms of embedded technology and functioning procedures. Several AMS generations have passed and significant have been made over the years. DeLaval (http://www. delaval.com/en/), Lely (https://www.lely.com/ br/) and Gea (https://www.gea.com/index.jsp) are examples of big companies that manufacture and sell AMS around the world.

DeLaval has just launched the second version of AMS equipment. The first model, known as VMS, was released in 1997. Over the years, new technologies have been incorporated, and the software has been updated. The current model (VMS V300) was launched in 2018, it comprises many important innovations concerning the 
previous one, namely: (i) coupling system of teat cups using smart cameras (DeLaval InSight $^{\mathrm{TM}}$ ), which can detect the udder and learn the way to reach teats faster, providing a smoother coupling with a higher attachment rate (99\%) and reduction in chemical consumption; (ii) cleaning system (DeLaval PureFlow ${ }^{\mathrm{TM}}$ ) with increased visibility, easier inspection, and more efficiency; (iii) new milk path between teat and tank, providing less impact and more care of milk, reducing free fatty acids and water consumption; and (iv) automated separation system of abnormal milk (culling, calf, etc.). According to the company itself, after such innovations sales volume of the AMS have increased sharply all over the world (DeLaval company data).

Lely launched its first system onto the market in 1992. Recently, the company has deactivated some units of its first AMS, which had operated for more than 20 years in Europe. Some of these were able to milk almost 15 million liters during their use in farms. The latest version of Lely AMS, launched in 2018 and called Astronaut A5, has some advantages over the previous systems: a) in-line reading of solids in milk; b) automatic separation of waste milk; and c) improved management system. Lely's equipment has an important exclusivity factor, which is to be the only one on the market that allows cows to enter the box straightly without making turns. This is the so-called I-flow (data from the company: Lely Industries N.V.).

In the United States, DeLaval, Lely, and GEA are the largest companies, but AMS-Galaxy and Boumatic Robotics are also operating on the market. In Europe, AMS is produced by SAC (Sacmilking) and Fullwood Packo.

\section{Advantages of AMS}

Many are the advantages of using AMS. Yet, according to Hansen (2015), to be successful, ranchers have to spend part of the time saved in milking in monitoring cows and robots. Besides, they need a minimal interest in technology as well as a proactive behavior to adapt it to their needs.

According to Tse et al. (2017, 2018b), AMS benefits to farmers are several: higher mean frequency of milking events and milk production; better herd health and reproductive rates; potential for better herd management regarding information collection and management; fewer workforce needs and increased labor flexibility; greater profitability and quality of life for owners.

In a study of 217 farms in eight Canadian provinces, Tse et al. (2018b) found that transitioning to an AMS was generally positive. Moreover, AMS improved profitability, quality of life of farmers, and cow welfare, thus meeting expectations. The main challenges while transitioning were learning and using the technology and generated data, as well as training of cows in the first days after changing the milking system.

\section{Increase in milk yield}

French data show an average growth of around $3 \%$ in milk production on farms adopting AMS, and up to $9 \%$ on farms milking by robots for more than two years (Veysset, Wallet, \& Prognard, 2001). Such a rise is mainly due to a potential increase in the mean number of milking events since AMS introduction (Dijkhuizen, Huirne, Harsh, \& Gardner, 1997; Rotz, Coiner, \& Soder, 2003).

Bar-Peled et al. (1995) showed that, when implemented at the beginning of lactation, a high milking frequency has potential to ensure increased milk production throughout the entire lactation period even if such frequency is decreased thereafter. These findings corroborate several other studies (Hale et al., 2003; Dahl et al., 2004; Eslamizad et al., 2010). These researchers confirmed the thesis about milk increase during all lactation, even if milking frequency increases only at the beginning. Besides, they realized that there is still a possible reduction in somatic milk cell counts when cows are milked more often during the day. Erdman and 
Varner (1995) reported a potential growth of up to $25 \%$ in productivity when cows previously milked just twice are milked three times a day. Lopes, Nogueira and Barbosa (2014), a broad overview of the literature shows an average increase of $14.75 \%$. Therefore, the goal is to allow access to the AMS by high productive-potential lactating cows more often, so an average number of milking events close to three milking a day per cow or above could be reached.

As higher milking frequency increase milk production, an important question is how to make cows access the AMS more often. Salfer, Minegishi, Lazarus, Berning and Endres (2017) reported that AMS management system should be properly parameterized so that the right cow could occupy the AMS at the right time. Early lactating cows, which theoretically seek more the AMS during the day, should have a greater number of permissions to access the equipment and be milked. According to some authors, such a strategy is essential to increase milked volume in an AMS.

According to Endres and Salfer (2015), there are two other key factors to achieve high milk productions in the system. The herd must consist of high production cows and occupy the AMS box for as little as possible, i.e., a high milk flow in $\mathrm{kg} \mathrm{min}$ ${ }^{1}$. Also, following these authors, the ultimate goal is to achieve high milk production per AMS, using minimal employees and fetch cows as possible. Different conditions can allow farmers to reach such a goal, namely: well-balanced and managed diet (either partial or total mixed ration), herds of high genetic level, excellent reproductive efficiency, good udder conformation, daily AMS maintenance, cows with higher milk flow per milking.

AMS is fully feasible to increase average milk production per cow on a farm. But it strongly depends on farmer ability to raise the number of total visits to the robot, mainly for cows at the beginning of lactation. Indeed, the AMS and herd management system have to be properly parameterized. Thus, beginning-lactation cows should be milked more often a day instead of middle- and end-lactation ones to increase total milk yield (Endres \& Salfer, 2015).

When comparing the effects of AMS and traditional tandem milking parlor on buffalo (Bubalus bubalis) milk yield, Sannino et al. (2018) observed that that the AMS use had significantly higher daily milk yield and lactation persistence.

\section{Better feed conversion}

Another important gain in farms using AMS is reported by Salfer et al. (2017). They stated that supplying pelleted feed to cows in the AMS box could strongly interfere with herd body condition and potentially increase milk production. This result is related to individual herd management, wherein each animal is recognized individually by the system. Thus, concentrate is supplied in the right amount based on nutritional demand estimated by the amount of milk the cow is producing.

According to Rodenburg (2011) and Bach and Cabrera (2017), supplying AMS concentrate is a strategy to lure cows to it. Besides, different concentrate amounts and types could be supplied. Thus, manufacturers were encouraged to suggest that such a strategy could reduce fetch-cow rates and accurately address precision nutrition.

AMS manufacturers and suppliers have considered feeding herds using AMS. Here follows the protocol of Lely, which only sells and works with AMS in free flows. The company recommends, for free flow milking, offering PMR (partial mixed ration) on the feedpad, by which about $80 \%$ of the nutritional request is met. The other $20 \%$ must be delivered in the AMS using only concentrate, preferably pelleted. These $20 \%$ function as lures to attract cows to the AMS box (data from the company Lely Industries N. V.).

According to actual data fromAMS manufacturers on client farms, a feed conversion rate of $1 \mathrm{~kg}$ of 
total concentrate consumed was estimated for each $3.3 \mathrm{~kg}$ milk produced. In conventional farms, where TMR diets are offered to cows divided into standard production batches, the best rates achieved were $1 \mathrm{~kg}$ total concentrate consumed per $2.5 \mathrm{~kg}$ milk produced (data from the companies DeLaval and Lely Industries N.V.).

\section{Labor cost reduction}

According to De Koning (2010), the world's first AMS in a commercial farm in the Netherlands in 1992 was established because of a significant increase in labor costs in that country. Rodenburg (2017) noted that robotic milking reduces labor demands on all size dairy farms and offers a more flexible lifestyle for farm families with up to 250 cows. This can be considered another important benefit of milking operation using AMS. Bijl, Kooistra and Hogeveen (2007) reported that Dutch farms using AMS had an average of 74 cows per full-time employee, while those using conventional milking systems had an average of 59 per employee. Minnesota's Farm Business Management Association (Finbin, 2016) have reported that farms in the Upper Midwest with AMS averaged over 1 million $\mathrm{kg}$ milk per full-time employee in one year, while conventional milking farms had only $700,000 \mathrm{~kg}$ per worker. Obviously, as reported by Svennersten-Sjaunja and Pettersson (2008), effective labor-hiring reductions in farms should be preceded by a proper herd flow management in free or forced flows, which are the most widely used worldwide. For these researchers, the ultimate goal is to achieve the largest possible number of milking visits in the AMS and, to reach this, AMS manufacturers often recommend a good concentrate supplementation per AMS, which is used to attract animals.

When comparing both flow systems, several authors (Ketelaar-de Lauwere et al., 1998; Bach et al., 2009) have already described that a guided flow requires less labor than the free flow. Such reduction can be even greater when automatic grazing technologies are used. Drach, Halachmi, Pnini, Izhaki and Degani (2017) suggested a new concept of bringing all cows into the AMS by using an Automatic Herding System (AHS), which consists of slow-moving fences. The authors observed that, when an AHS was used on a commercial farm in Israel, the working time of cow fetching to the AMS reduced by $80 \%$ compared to the experimental group. They also associated the use of this technology to higher milk frequency and higher milk yield. Therefore, economic benefits are expected from this technique.

\section{Less civil construction needs}

One of the benefits of a robotic milking system is a reduction in the need for civil works. As AMS facilities are less complex, the amount invested in facilities can be significantly reduced both in terms of absolute value, smaller built-up area, or relative value, less building complexity.

A publication by Carregosa and Almeida (2015), in partnership with Lely on website agronegocios. eu, states that civil work to install an AMS is minimal compared to that required by a conventional milking parlor and is therefore much more economical.

The design of facilities is quite important because, according to Jacobs, Ananyeva and Siegford (2012b), it can affect AMS accessibility. In particular, positioning of gates and corridors around an AMS can affect cow traffic and behavior, and therefore time available for milking. The importance of good design and layout was also highlighted by Lyons et al. (2013) and Rodenburg (2017).

\section{Good working environment and worker health}

Milker health concern can be a favorable argument for adopting AMS. Salfer et al. (2017) explained that many dairy farmers have invested in AMS due to a growing concern about the health of knees, back, hips, and shoulders of their milking officers. 


\section{Milk quality improvement}

Some researchers, such as Hale et al. (2003), Dahl et al. (2004) and Eslamizad et al. (2010), found that AMS, by providing a higher average number of milking events, can significantly reduce somatic cell counts in milk. Likewise, Dohmen, Neijenhuis and Hogeveen (2010) surveyed 144 farms using AMS in Germany and observed a strong positive relationship between low somatic cell count in milk with quality in cow hygiene and successful teat disinfection. According to these authors, robotized farms have better conditions and structure for such results.

Compared to a traditional tandem milking parlor, the use of AMS resulted in higher protein and casein contents and lower somatic and total bacterial counts, whereas fat, freezing point and $\mathrm{pH}$ were not affected by the systems (Sannino et al., 2018). The authors concluded that, in terms of milk production and quality, AMS may be a feasible alternative to the conventional milking for buffaloes.

\section{Information management and decision making}

The main differences between AMS and conventional milking are computerized monitoring, individual analysis and control of animals, transparently to the users, allowing online acquisition and processing of individual cows with unprecedented details (Spahr \& Maltz, 1997).

According to King, Dancy, Leblanc, Pajor and De Vries (2017a) and King, Leblanc and De Vries (2017b), AMS is capable of generating large amounts of data and important information for the farmer, usually combined with electronic monitoring/ behavior monitoring, rumination and activity level systems. This management system can also generate many alerts and reports of various types, which can help managers a lot in different and necessary decision-making processes in a daily livestock activity.
In the studies of King et al. (2017a,b), they have shown, for example, that there is important evidence that ruminal behavior often changes in cases of any physiological, metabolic and/or sanitary disorders, before a reduction in milk production. According to them, in general, reductions in rumination time precedes milk yield and animal activity level reductions by at least one day. These authors observed that cows showed reductions in rumination time, body weight, daily activity, milk production, food intake, and visits to AMS, in addition to / or spending more time lying down before being diagnosed with pneumonia, subclinical ketosis, displacement of abomasum, metritis and/ or hoof problems.

Measurements of rumination, daily activity and milk production can allow detection of problems in advance and then perform corrections of existing abnormalities in a fast and strategic manner, without major losses. Such measurements are possible to be carried out by combined systems of AMS and specialized electronic monitoring systems. The importance of adopting such technologies is strictly linked to the ability of each farmer to handle such a volume of information and, of course, to know how to manage them (King et al., 2017a,b).

Jacobs and Siegford (2012a) argued that automatic sensors can memorize highly rich data sets regarding mammary health, daily and milking production, rumination time, and feed consumption in the AMS. Poppe, Mulder, Ducro and De Jong (2019) pointed out that cartesian teat coordinates measured by AMS provide new opportunities to record udder conformation characteristics, allowing studies on genetic and phenotypic changes within and between parities. For Hansen (2015), more data on herds can stimulate interest by ranchers in dairy production, but in many cases, they find themselves drowned in data. 


\section{Greater economic viability}

Adoption of AMS technology requires high investments, therefore, some factors must be considered to determine its economic feasibility. According to Salfer et al. (2017), aspects directly related to greater or lesser profitability of AMS are labor costs (which tend to grow), milk yield increase (which may be higher or lower in AMS, depending on flow management), investment values and equipment lifespan. They also pointed out that AMS problem is milking frequency that rarely reaches three per day, on average, and hardly yields the same milk daily volume as that of cows milked three times a day in a conventional system.

Hyde and Engel (2002) showed that investing in AMS can be more profitable or have a slightly lower break-even point than conventional milking, what is basically due to saving on labor cost and increase in milk yield. Furthermore, still on the break-even point, the results of more recent research should be highlighted, such as those mentioned by Salfer et al. (2017). These authors simulated some scenarios to compare economic performances between farms using AMS and CMS (conventional milking system) and asked the following question: what milk volume would be needed on farms with about 1,500 lactating-cow herds for an AMS to have similar economic performance as farms with CMS? They found that if an AMS-equipped farm could reach around $1.4 \mathrm{~kg}$ more milk per cow compared to a CMS-equipped, with a $1 \%$ increase in labor costs, its net performance could be almost US \$ 17 thousand more cash into the farm. If labor cost increases are of $3 \%$, such volume could be about $0.45 \mathrm{~kg}$ only.

Salfer et al. (2017) also simulated some scenarios for the comparison of economic performances between AMS- and CMS-equipped farms, with labor cost increases ranging from $1 \%$ to $3 \%$. They found that on farms with up to 240 lactating cows, AMS-equipped properties were more capable to support variations in workforce wages. So, when labor costs varied by $3 \%$, economic performance in farms using AMS was US \$32,000 higher than CMS ones.

However, on larger herd farms (e.g., about 1,500 lactating cows), the study showed that CMS is more profitable than AMS. According to the authors, it is because of the efficient use of milking equipment. For smaller farms, AMS always brought results closer to the maximum capacity than did the CMS, while in larger ones, both AMS and CMS had similar operational and efficiency levels, thus, a higher milk volume diluted labor cost.

\section{Other advantages}

Improving herd and family-time managements was more influential for small and medium-sized farms in the states of Maryland and Pennsylvania when considered transitional period for adopting AMS (Moyes, Ma, McCoy, \& Peters, 2014).

\section{Some disadvantages of AMS}

\section{High investment}

The first and perhaps most striking problem related to AMS is precisely its high purchase and installation costs. According to Maculan and Lopes (2016), investment costs in AMS in Brazil can reach R \$ 19,000.00 (or about US \$5,250.00 at the time of the survey) per head, and payback can take eight to 10 years.

A recent quote by DeLaval in 2018 (access granted to authors) presented value in the order of R \$ 740,000.00 (or US\$ 195,000.00) for acquisition and implementation of the newest AMS unit (DeLaval VMS V300). It consists of a milk-first system capable of milking about 70 cows on average in a compost dairy barn. In a study by Maculan and Lopes (2016), the total value for the same 70 cows would reach US\$367,500.00. The quotation cited above basically refers to the AMS itself (complete) and some essential accessories: AMS, double 
filter, electrical protection board, milk discharge line, milk and cleaning piping, air compressor, gates and sensors for guided flow, sampler and lung tank. Maculan and Lopes (2016) did not present investment details. According to Hyde and Engel (2002), AMS purchase value differs among manufacturers and models, with prices varying between US\$175,000 and US\$250,000.

\section{Free fatty acids (FFAs) in milk}

Studies have reported increased levels of FFAs in some farms after the adoption of AMS (Justesen \& Rasmussen, 2000). High levels of milk FFAs are undesirable for promoting sensory changes and shortening shelf life and milk yield (Tuckey \& Stadhouders, 1967; Sapru et al., 1997). Several other studies have shown that such increase in FFAs in AMS farms may be due to increased frequency and lower milking intervals, impacting the size of fat globules and making them more susceptible to lipolysis (Ahrne \& Bjork, 1985; Ipema \& Schuiling, 1992; Klein et al., 1997; Wiking, Bjork, \& Nielsen, 2003; Wiking, Nielsen, Bavius, Edvardsson, \& Svennersten-Sjaunja, 2006).

\section{Changes in fat and protein contents}

According to Bach et al. (2009), some guided flow systems such as milk-first or feed-first tend to decrease milk solids (fat and protein). Fats tend to drop due to an increased potential for ruminal acidosis. For these authors, in a guided flow, cows consume larger feed amounts at once, as it will take longer to access the feeding alley again. Proteins, however, fall precisely due to a reduction in total dry matter consumption, also observed in guided (or forced) flow systems, mainly when water access is restricted.

\section{Increase in subclinical ketosis}

According to Tatone, Duffield, Leblanc, De Vries and Gordon (2017) and King, Sparkman,
Leblanc and De Vries (2018), subclinical ketosis rates tend to increase in dairy herds under AMS. The reason is related to the increase in the number of milking events and milk production inherent to the AMS, especially at the beginning of lactation. Also, King et al. (2018) reported that these dairy cows tend to produce more milk than those under the conventional system for entering a slightly more serious negative energy balance. Therefore, since these cows do not increase feed intake to the same extent, subclinical ketosis may eventually occur.

AMS allows higher milking frequencies than conventional systems, providing higher milk yields (Wagner-Storch \& Palmer, 2003; Bogucki, Sawa, \& Neia, 2014; Sitkowska, Piwczynski, Aerts, \& Waskowicz, 2015; De Marchi, Penasa, \& Cassandro, 2017). This can worsen negative energy balance and risk of subclinical ketosis, corroborating the results of another study. This study demonstrated that AMS herds have a prevalence of high rates of betahydroxybutyrate than those in conventional milking systems (Tatone et al., 2017). As for King et al. (2018), cows producing more milk have more betahydroxybutyrate circulating in the blood, as well as a higher probability of having subclinical ketosis. According to these authors, cows that produce less are more able to obtain from the diet the energy they need.

\section{Other disadvantages}

For ranchers in Jæren, Norway, the greatest disadvantage of an AMS is the constancy of service (Hansen, 2015). Return on investment or changes in profitability and management were the main concerns of small and medium farmers in the states of Maryland and Pennsylvania, considering the transition period for an AMS (Moyes et al., 2014). Tse et al. (2018b) assessed 217 farmers in eight Canadian provinces and noted that, on average, $2 \%$ of a herd had to be slaughtered for not adapting or not voluntarily milking, although it is physically and behaviorally normal. 


\section{Final considerations}

Some of the topics covered in this review require new studies and research to be supported in a more forceful and consolidated way in the dairy sector and even in the academic environment.

Dairy cattle projects using AMS have grown significantly worldwide, especially in the last two years, according to data from manufacturers and suppliers (DeLaval, Lely and Gea). Increased production costs and a small evolution in labor quality and consequent turnover in farms made dairy ranchers, especially new ones, consider investing in AMS.

Nowadays, AMS technology is much better mastered both by the manufacturing companies and the farmers who have adopted it. It presents numerous technological innovations to fully transforming everyday life within a dairy farm. Its adoption, therefore, depends on the actual ability of farmers to become entrepreneurs and the farm to a company. For proper AMS functioning, some factors have to be improved such as reproductive efficiency, diet quality and adequacy, and animal genetic potential. Therefore, the focus on farm management, strategic decision-making, and assembly of excellence teamwork must be maintained.

However, it must be emphasized that robotization is not for everyone. Differences between AMS and conventional systems are quite challenging and complex. It is prominent to understand that AMS use strongly reduces human interference in the milking process and that cows are motivated to voluntarily access the system, especially when attracted by feedstuffs. Many farmers who choose to switch from conventional milking to AMS believe they will have a chance to reduce the volume and improve the quality of work.

Any novice farmers should, therefore, make all feasible and necessary investment analyses, seek local labor availability, consult with the manufacturers, and visit farms that have already implemented AMS, so that they could understand challenges to be faced and any problems that may arise.

Besides the aforementioned, farmers who opt to switch from conventional to AMS also have to understand that other activities within the farm must be improved and more qualified, mainly those in sectors that are crucial for AMS to function with excellence such as animal nutrition and reproduction, as well as management of data generated by monitoring.

Milk yield increase, labor reduction and flexibility, more motivated teams, reduced concentrate cost, better reproduction rates, better milk quality, improved diets, healthier herd, equipment durability, and return on investment are the main objectives to be pursued by farmers who choose to invest in AMS. When deciding to invest, farmers must keep in mind all possible information, set goals, form a motivated and capable team, and focus on the activity. All AMS advantages are feasible but require presence. And, without management, all disadvantages can lead to project failure.

As for high investments, when deciding to adopt AMS technology, some factors must be considered to determine its economic viability, namely: labor costs (which tend to increase), increase in milk production after the adoption of AMS, investment values and equipment lifespan. A fundamental aspect to enable technology acquisition is bank financing with interest rates consistent with rural and business activities. Such investments can ensure the permanence of farmers in the dairy activity, and hence the supply of such noble food to the population.

\section{References}

Ahrne, L., \& Bjork, L. (1985). Lipolysis and the distribution of lipase activity in bovine milk in relation to stage of lactation and time of milking. Journal of Dairy Research, 52(1), 55-64. doi: 10.1017/S00220 2990002389X 
Bach, A., \& Cabrera, V. (2017). Robotic milking: feeding strategies and economic returns. Journal of Dairy Science, 100(9), 7720-7728. doi: 10.3168/jds.201611694

Bach, A., Devant, M., Igleasias, C., \& Ferrer, A. (2009). Forced traffic in automatic milking systems effectively reduces the need to get cows, but alters eating behavior and does not improve milk yield of dairy cattle. Journal of Dairy Science, 92(3), 12721280. doi: $10.3168 /$ jds.2008-1443

Bach, A., Dinarés, M., Devant, M., \& Carré, X. (2007). Associations between lameness and production, feeding and milking attendance of Holstein cows milked with an automatic milking system. Journal of Dairy Research, 74(1), 40-46. doi: 10.1017/ S0022029906002184

Bar-Peled, U., Maltz, E., Bruckental, I., Kali, Y., Gacitua, H., Lehrer, A. R.,... Tagari, H. (1995). Relationship between frequent milking or suckling in early lactation and milk production of high producing dairy cows. Journal of Dairy Science, 78(12), 27262736. doi: 10.3168/jds.S0022-0302 (95)76903-X

Bijl, R., Kooistra, S. R., \& Hogeveen, H. (2007). The profitability of automatic milking on Dutch dairy farms. Journal of Dairy Science, 90(1), 239-248. doi: 10.3168/jds.S0022-0302(07)72625-5

Bogucki, M., Sawa, A., \& Neia, W. (2014). Effect of changing the cow milking system on daily yield and cytological quality of milk. Acta Scientiarum Polonorum. Zootechnica, 13(4), 17-26. Retrieved from http://scholar.googleusercontent.com/schol ar? $q=$ cache:bNNt5joX61IJ:scholar.google.com/+ Bogucki, +M.,+Sawa,+A.,+\%26+Neia,+W.+(201 4). + Effect + of + changing + the + cow + milking + syste $\mathrm{m}+\mathrm{on}+$ daily + yield + and + cytological + quality + of + milk.+Acta+Scientiarum+Polonorum.+Zootechni ca, $+13(4),+17-26 .+$ doi: $+\& h l=p t-B R \& a s \_s d t=0,5$

Carregosa, I., \& Almeida, O. (2015). O Robot de ordenha e a Lely 20 anos depois... a ordenha automática é realmente voluntária? Retrieved from http://www. agronegocios.eu/noticias/o-robot-de-ordenha-ea-lely- 20-anos-depois-a-ordenha-automatica-erealmente-voluntaria/

Dahl, G. E., Wallace, R. L., Shanks, R. D., \& Lueking, D. (2004). D. Hot topic: effects of frequent milking in early lactation on milk yield and udder health. Journal of Dairy Science, 87(4), 882-885. doi: 10. 3168/jds.S0022-0302(04)73232-4

De Koning, K. (2010). Automatic milking Common practice on dairy farms. Proceedings of the North
American Conference on Robotic Milking, The First North American Conference on Precision Dairy Management. Toronto, Elora, Canada, 2.

De Marchi, M., Penasa, M., \& Cassandro, M. (2017). Comparison between automatic and conventional milking systems for milk coagulation properties and fatty acid composition in commercial dairy herds. Italian Journal of Animal Science, 16(3), 363-370. doi: 10.1080/1828051X.2017.1292412

De Vries, T. J., Von Keyserlingk, M.A. G., \& Beauchemin, K. A. (2005). Frequency of feed delivery affects the behavior of lactating dairy cows. Journal of Dairy Science, 88(10), 3553-3562. doi: 10.3168/jds. S0022-0302(05)73040-X

Dijkhuizen, A. A., Huirne, R. B. M., Harsh, S. B., \& Gardner, R. W. (1997). Economics of robot application. Computers and Electronics in Agriculture, 17(1), 111-121. doi: 10.1016/S01681699(96)01228-8

Dohmen, W., Neijenhuis, F., \& Hogeveen, H. (2010). Relationship between udder health and hygiene on farms with an automatic milking system. Journal of Dairy Science, 93(9), 4019-4033. doi: 10.3168/ jds.2009-3028

Drach, U., Halachmi, I., Pnini, T., Izhaki, I., \& Degani, A. (2017). Automatic herding reduces labour and increases milking frequency in robotic milking. Biosystems Engineering, 155(2017), 134-141. doi: 10. 1016/j.biosystemseng.2016.12.010

Dzidic, A., Macuhova, J., \& Bruckmaier, R. M. (2004). Effects of cleaning duration and water temperature on oxytocin release and milk removal in an automatic milking system. Journal of Dairy Science, 87(12), 4163-4169. doi; 10.3168/jds.S0022-0302(04)735596

Empresa Brasileira de Pesquisa Agropecuária (2018). Embrapa Anuário Leite 2018. Indicadores, tendências e oportunidades para quem vive no setor leiteiro. Retrieved from http://www.embrapa.br/ gado-de-leite

Endres, M. I., \& Salfer, J. A. (2015) An evaluation of automated milking systems in the Midwest United States. Journal Dairy Science, 98(Suppl. 2), 114 (Abstract).

Erdman, R. A., \& Varner, M. (1995). Fixed yield responses to increased milking frequency. Journal of Dairy Science, 78(5), 1199-1203. doi: 10.3168/jds. S0022-0302(95)76738-8 
Eslamizad, M., Dehghan-Banadaky, M., Rezayazdi, K., \& Moradi-Shahrbabak, M. (2010). Effects of 6 times daily milking during early versus full lactation of Holstein cows on milk production and blood metabolites. Journal of Dairy Science, 93(9), 40544061. doi: 10.3168/jds.2010-3104

Ferrazza, R. de A., Lopes, M. A., Bruhn, F. R. P., Moraes, F., \& Carvalho, F. de M. (2017). Effect of husbandry system on the technical and economic performance of dairy cattle. Semina: Ciências Agrárias, 38(3), 1561-1574. doi: 10.5433/1679-0359.2017v38n $3 \mathrm{p} 1561$

The Farm Financial Management Database Finbin (2016). Livestock: dairy summary report. Center for Farm Financial Management. University of Minnesota. Retrieved from https://finbin.umn. edu

Halachmi, I., Ofir, S., \& Miron, J. (2005). Comparing two concentrate allowances in an automatic milking system. Animal Science, 80(3), 339-344. doi: 10.1079/ASC40480339

Hale, S. A., Capuco, A. V., \& Erdman, R. A. (2003). Milk yield and mammary growth effects due to increased milking frequency during early lactation. Journal of Dairy Science, 86(6), 2061-2071. doi: 10. 3168/jds. S0022-0302(03)73795-3

Hansen, B. G. \& Jervell, A. M. (2015). Change Management in Dairy Farming. The International Journal of Sociology of Agriculture and Food, 22(1), 23-40. Retrieved from https://nmbu.brage.unit. no/nmbu-xmlui/bitstream/handle/11250/2387162/ IntJourofSocofAgrandFood.pdf? sequence $=3$

Hare, K., De Vries, T. J., Schwartkopf-Genswein, K. S., \& Penner, G. B. (2018). Does the location of concentrate provision affect voluntary visits, and milk and milk component yield for cows in an automated milking system? Canadian Journal of Animal Science, 98(2), 399-404. doi: 10.1139/cjas2017-0123

Harms, J., Wendl, G., \& Schon, H. (2002). Influence of cow traffic on milking and animal behaviour in a robotic milking system. First North American Conference on Robotic Milking (Proceedings), Toronto, Canada, 1, 492-495.

Hogeveen, H., Ouweltjes, W., De Koning, C. J. A. M., \& Stelwagen. K. (2001a). Milking interval, milk production and milk flow-rate in an automatic milking system. Livestock Production Science, 72(12), 157-167. doi: 10.1016/S0301-6226(01)00276-7

Hogeveen, H., Vandervorst, Y., De Koning, C., \& Slaghuis, B. (2001b). Concepts and implications of automatic milking. Proceedings of the Symposiumsur Les Bovins Laitiers, Quebec, Canada, 25. Retrieved from http://www.agrireseau.qc.ca/bovins-laitiers/ Documents/2001_Hogeveen_anglais.pdf

Hyde, J., \& Engel, P. (2002). Investing in a robotic milking system: a Monte Carlo simulation analysis. Journal of Dairy Science, 85(9), 2207-2214. doi: 10.3168/jds.S0022-0302(02)74300-2

Ipema, A. H., \& Schuiling, E. (1992). Free fatty acids; influence of milking frequency. Proceedings of the Symposium on Prospects for Automatic Milking, Pudoc Scientific Publishers, 65, 244-252. Wageningen, The Netherlands.

Jacobs, J. A., \& Siegford, J. M. (2012a). Invited review: The impact of automatic milking systems on dairy cow management, behavior, health, and welfare. Journal of Dairy Science, 95(5), 2227-2247. doi: 10. 3168/jds.2011-4943

Jacobs, J. A., Ananyeva, K., \& Siegford, J. M. (2012b). Dairy cow behavior affects the availability of an automatic milking system. Journal of Dairy Science, 95(4), 2186-2194. doi: 10.3168/jds.2011-4749

John, A. J., Cullen, B. R., Oluboyede, K., Freeman, M. J., Kerrisk, K. L., Garcia, S. C., \& Clark, C. E. F. (2019). The effect of pasture quantity temporal variation on milking robot utilization. Journal of Dairy Science, 102(3), 2551-2559. doi: 10.3168/jds.2018-14801

Justesen, P., \& Rasmussen, M. D. (2000). Improvements of milk quality by the Danish AMS self monitoring programme. Proceedings of the International Symposium Robotic Milking, Lelystad, The Netherlands.

Ketelaar-de Lauwere, C. C., Hendriks, M. M. W. B., Metz, J. H. M., \& Schouten, W. G. P. (1998). Behavior of dairy cows under free or forced cow traffic in a simulated automatic milking system environment. Applied Animal Behavior Science, 56(1), 13-28. doi: 10.1016/S0168-1591(97)00076-2

Ketelaar-de Lauwere, C. C., Hendriks, M. M. W. B., Zondag, J., Ipema, A. H., Metz, J. H. M., \& Noordhuizen, J. P. T. M. (2000). Influence of routing treatments on cows' visits to an automatic milking system, their time budget and other behavior. Acta Agriculture Scandinavica, Section A, Animal Science, 50(3), 174-183. doi: 10.1080/090647000750014304

King, M. T. M., Dancy, K. M., Leblanc, S. J., Pajor, E. A., \& De Vries, T. J. (2017a). Deviations in behavior and productivity data before diagnosis of health disorders in cows milked with an automated system. Journal of Dairy Science, 100(10), 8358-8371. doi: $10.3168 /$ jds.2017-12723 
King, M. T. M., Leblanc, S. J., \& De Vries, T. J. (2017b). Cow-level associations of lameness, behavior, and milk yield of cows milked in automated systems. Journal of Dairy Science, 100(6), 4818-4828. doi: 10. 3168/jds.2016-12281

King, M. T. M., Sparkman, K. J., Leblanc, S. J., \& De Vries, T. J. (2018). Milk yield relative to supplement intake and rumination time differs by health status for fresh cows milked with automated systems. Journal of Dairy Science, 101(11), 10168-10176. doi: $10.3168 /$ jds.2018-14671

Klei, L. R., Lynch, J. M., Barbano, D. M., Oltenacu, P. A., Lednor, J., \& Bandler, D. K. (1997). Influence of milking three times a day on milk quality. Journal of Dairy Science, 80(3), 427-436. doi: 10.3168/ jds. S0022-0302(97)75954-X

Lopes, M. A., Moraes, F. de, Carvalho, F. M., Peres, A. C. C., Bruhn, F. R. P., \& Reis, E. M. B. (2015). The effect of technological levels on profits of milk production systems participating in the "full bucket" program: a multicase study. Semina: Ciências Agrárias, 36(4), 2909-2922. doi: 10.5433/16790359 . 2015v36n4p2909

Lopes, M. A., Moraes, F., Carvalho, F. M., Peres, A. A. C., Bruhn, F. R. P., \& Reis, E. M. B. (2016). Effect of technical indexes on cost-effectiveness in dairy farms participating in the "Balde Cheio" program at different stages of production. Semina: Ciências Agrárias, 37(6), 4235-4242. doi: 10.5433/16790359. 2016v37n6p4235

Lopes, M. A., Nogueira, T. M., \& Barbosa, G. L. (2014). Economic viability of the third milking in systems of production using closed-circuit mechanical milking. Revista Ceres, 61(4), 544-551. doi: 10.1590/ 0034$737 \mathrm{X} 201461040014$

Lyons, N. A., Kerrisk, K. L., \& Garcia, S. C. (2013). Effect of pre-versus postmilking supplementation on traffic and performance of cows milked in a pasturebased automatic milking system. Journal of Dairy Science, 96(7), 4397-4405. doi: 10.3168/jds.20126431

Lyons, N. A., Kerrisk, K. L., \& Garcia, S. C. (2014). Milking frequency management in pasture-based automatic milking systems: a review. Livestock Science, 159(2014), 102-116. doi: 10.1016/j.livsci. 2013.11.011

Maculan, R., \& Lopes, M. A. (2016). Ordenha robotizada de vacas leiteiras: uma revisão. Boletim de Indústria Animal, 73(1), 80-87. doi: 10.17523/bia.v73n1p80
Melin, M., Pettersson, G., Svennersten-Sjaunja, K., \& Wiktorsson, H. (2007). The effects of restricted feed access and social rank on feeding behavior, ruminating and intake for cows managed in automated milking systems. Applied Animal Behavior Science, 107(12), 13-21. doi: 10.1016/j.applanim.2006. 09.026

Melin, M., Svennersten-Sjaunja, K., \& Wiktorsson, H. (2005). Feeding patterns and performance of cows in controlled cow traffic in automatic milking systems. Journal of Dairy Science, 88(11), 3913-3922. doi: 10.3168/jds.S0022-0302(05)73077-0

Menajovsky, S. B., Walpole, C. E., De Vries, T. J., Schwatzkopf-Genswein, K. S., Walpole, M. E., \& Penner, G. B. (2018). The effect of the forage-toconcentrate ratio of the partial mixed ration and the quantity of concentrate in an automatic milking system for lactating Holstein cows. Journal of Dairy Science, 101(11), 9941-9953. doi: 10.3168/jds.201814665

Migliorati, L., Speroni, M., Lolli, S., \& Calza, F. (2005). Effect of concentrate feeding on milking frequency and milk yield in an automatic milking system. Italian Journal of Animal Science, 4(Suppl. 2), 221223. doi: $10.4081 /$ ijas.2005.2s.221

Moraes, F., Lopes, M. A., Carvalho, F. M., Peres, A. A. C., Bruhn, F. R. P., Lima, A. L. R., \& Cardoso, M. G. (2018). Effect of the scale of production on the cost-effectiveness of milk production systems belonging to the "Balde Cheio" program. Semina: Ciências Agrárias, 39(3), 1211-1224. doi: 10.5433/ 1679-0359.2018v39n3p1211

Moyes, K. M., Ma, L., McCoy, T. K., \& Peters, R. R. (2014). A survey regarding the interest and concern associated with transitioning from conventional to automated (robotic) milking systems for managers of small-to medium-sized dairy farms. The Professional Animal Scientist, 30(4), 418-422. doi: 10.15232/ pas.2014-01327

Nieman, C. C., Steensma, K. M., Rowntree, J. E., Beede, D. K., \& Utsumi, S. A. (2015). Differential response to stocking rates and feeding by two genotypes of Holstein-Friesian cows in a pasture-based automatic milking system. Animal, 9(12), 2039-2049. doi: 10.1017/S1751731115001901

Paiva, C. A. V., Pereira, L. G. R., Tomich, T. R., \& Possas, F. P. (2015). Sistema de ordenha automático. Cadernos Técnicos de Veterinária e Zootecnia, (79), 41-53. Retrieved from https://www.alice. cnptia.embrapa.br/bitstream/doc/1037874/1/ Cnpg12015CadTecVetZootSistema.pdf 
Poppe, M., Mulder, H. A., Ducro, B. J., \& De Jong, G. (2019). Genetic analysis of udder conformation traits derived from automatic milking system recording in dairy cows. Journal of Dairy Science, 102(2), 13861396. doi: /10.3168/jds.2018-14838

Rodenburg, J. (2011). Designing feeding systems for robotic milking. Proceedings of the Tri-State Dairy Nutrition Conference, 127-138. Ft. Wayne, Indiana, USA. Retrieved from https:/www.researchgate. net/ profile/Jack_Rodenburg/publication/265084870 Designing_Feeding_Systems_for_Robotic_ Milking/links/563e7b6a08aec6f17ddaaa3d.pdf

Rodenburg, J. (2017). Robotic milking: technology, farm design, and effects on work flow. Journal of Dairy Science, 100(9), 7729-7738. doi: 10.3168/jds.201611715

Rotz, C. A., Coiner, C. U., \& Soder, K. J. (2003). Automatic milking systems, farm size, and milk production. Journal of Dairy Science, 86(12), 41674177. doi: 10.3168/jds.S0022-0302(03)74032-6

Salfer, J. A., Minegishi, K., Lazarus, W., Berning, E., \& Endres, M. I. (2017). Finances and returns for robotic dairies. Journal of Dairy Science, 100(9), 7739-7749. doi: 10.3168/jds.2016-11976

Sannino, M., Faugno, S., Crimaldi, M., Di Francia, A., Ardito, L., Serrapica, F., \& Masucci, F. (2018). Effects of an automatic milking system on milk yield and quality of Mediterranean buffaloes. Journal of Dairy Science, 101(9), 8308-8312. doi: 10.3168/ jds.2017-14157

Santos, C. C., Almeida, G. A. de, Jr., \& Lopes, M. A. (2018). Dairy activity in family farming in Minas Gerais, Brazil: production costs and costeffectiveness analysis. Semina: Ciências Agrárias, 39(3), 1255-1266. doi: 10.5433/1679-0359.2018v3 $9 \mathrm{n} 3 \mathrm{p} 1255$

Santos, G., \& Lopes, M. A. (2012). Indicador de rentabilidade do centro de custo de produção de leite em sistemas intensivos de produção. Boletim de Indústria Animal, 69(1), 1-11. Retrieved from http:/www. iz.sp.gov.br/bia/index.php/bia/article/ view/1042

Sapru, A., Barbano, D. M., Yun, J. J., Klei, L. R., Oltenacu, P. A., \& Bandler, D. K. (1997). Cheddar cheese: Influence of milking frequency and stage of lactation on composition and yield. Journal of Dairy Science, 80(3), 437-446. doi: 10.3168/jds.s00220302(97)75955-1

Shortall, J., Foley, C., Sleator, R. D., \& O'Brien, B. (2018a). The effect of dairy cow breed on milk production, cow traffic and milking characteristics in a pasture-based automatic milking system. Livestock Science, 209, 1-7. doi: 10.1016/j.livsci.2018.01.002

Shortall, J., O'Brien, B., Sleator, R. D., \& Upton, J. (2018b). Daily and seasonal trends of electricity and water use on pasture-based automatic milking dairy farms. Journal of Dairy Science, 101(2), 1565-1578. doi: $10.3168 /$ jds.2017-13407

Silva, G. R., Lopes, M. A., Lima, A. L., Costa, G. M., Damasceno, F. A., Barros, V. P., \& Barbari, M. (2019). Analysis of rentability of milk production systems in compost barn and free stall: a comparative. Semina: Ciências Agrárias, 40(3), 1165-1184. doi: 10.5433/1679-0359.2019v40n3p1165

Sitkowska, B., Piwczynski, D., Aerts, J., \& Waskowicz, M. (2015). Changes in milking parameters with robotic milking. Archives Animal Breeding Archiv Tierzucht, 58(1), 137-143. doi: 10.5194/aab-58-1372015

Spahr, S. L., \& Maltz, E. (1997). Herd management for robot milking. Computers and Electronics in Agriculture, 17(1), 53-62. doi: 10.1016/S01681699(96)01225-2

Svennersten-Sjaunja, K. M., \& Pettersson, G. (2008). Pros and cons of automatic milking in Europe. Journal of Animal Science, 86(Suppl. 13), 37-46. doi: $10.2527 /$ jas.2007-0527

Tatone, E. H., Duffield, T. F., Leblanc, S. J., De Vries, T. J., \& Gordon, J. L. (2017). Investigating the within-herd prevalence and risk factors for ketosis in dairy cattle in Ontario as diagnosed by the test-day concentration of $\beta$-hydroxybutyrate in milk. Journal of Dairy Science, 100(2), 1308-1318. doi: 10.3168/ jds.2016-11453

Thune, R. Ö. (2000). MS Thesis. The Agricultural University of Norway, Institutt for Tekniske Fag Às, Department of Animal Nutrition and Management, Norway; and Swedish University of Agricultural Sciences, Uppsala.

Trembley, M., Hess, J. P., Christenson, B. M., McIntyre, K. K., Smink, B., Van Der Kamp, A. J.,... Dopfer. D. (2016). Factors associated with increased milk production for automatic milking systems. Journal of Dairy Science, 99(5), 3824-3837. doi: 10.3168/ jds.2015-10152

Tse, C., Barkema, H. W., De Vries, T. J., Rushen, J., \& Pajor, E. A. (2017). Effect of transitioning to automatic milking systems on producers' perceptions of farm management and cow health in the Canadian dairy industry. Journal of Dairy Science, 100(3), 2404-2414. doi: 10.3168/jds.2016-11521 
Tse, C., Barkema, H. W., De Vries, T. J., Rushen, J., \& Pajor, E. A. (2018a). Impact of automatic milking systems on dairy cattle producers' reports of milking labour management, milk production and milk quality. Cambridge University Press, 12(12), 26492656. doi: $10.1017 / \mathrm{S} 1751731118000654$

Tse, C., Barkema, H. W., De Vries, T. J., Rushen, J., Vasseur, E., \& Pajor, E. A. (2018b). Producer experience with transitioning to automatic milking: Cow training, challenges, and effect on quality of life. Journal of Dairy Science, 101(10), 9599-9607. doi: $10.3168 /$ jds.2018-14662

Tuckey, S. L., \& Stadhouders, J. (1967). Increase in sensitivity of organoleptic detection of lipolysis in cows milk by culturing or direct acidification. Neth. Milk Dairy Journal, 21, 158-162. Retrieved from https://www.scopus.com/record/display.uri?eid=2s2.0-33745431498\&origin=inward\&txGid=7fa38d aa $3 \mathrm{e} 7912 \mathrm{ea} 0 \mathrm{ef} 9 \mathrm{~b} 34929 \mathrm{c} 276 \mathrm{bb}$

Veysset, P., Wallet, P., \& Prognard, E. (2001). Automatic milking systems: characterizing the farms equipped with AMS, impact and economic simulations. Conference on Physiological and Technical Aspects of Machine Milking, ICAR Technical Series, 7, 141-150. Retrieved from https://www.icar.org/ Documents/technical_series/ICAR-TechnicalSeries-no-7-Nitra/Veysset.pdf
Villela, S. D. J., Assis, L. P., Lopes, M. A., Silvestre, L. H. A., Santos, R. A., Resende, E. S., \& Martins, P. G. M. A. (2017). Economic and productive assessment of an ordinary small-sized dairy enterprise in southeast Brazil: A multi-year study. Journal of Agricultural Science, 9(8), 143-154. doi: 10.5539/jas. v9n8p143

Wagner-Storch, A. M., \& Palmer, R. W. (2003). Feeding behavior, milking behavior, and milk yields of cows milked in a parlor versus an automatic milking system. Journal of Dairy Science, 86(4), 1494-1502. doi: 10.3168/jds.S0022-0302(03)73735-7

Wiking, L., Bjork, L., \& Nielsen, J. H. (2003). Influence of feed composition on stability of fat globules during pumping of raw milk. International Dairy Journal, 13(10), 797-803. doi: 10.1016/S0958-6946 (03)00110-9

Wiking, L., Nielsen, J. H., Bavius, A. K., Edvardsson, A., \& Svennersten-Sjaunja, K. (2006). Impact of milking frequencies on the level of free fatty aci- ds in the milk, fat globule size, and fatty acid composition. Journal of Dairy Science, 89(3), 1004-1009. doi: 10.3168/jds.S0022-0302(06)72166-X

Wildridge, A. M., Thomson, P. C., Garcia, S. C., Jongman, E. C., Clark, C. E., \& Kerrisk, K. L. (2018). The impact of fetching at night on milking parlour visitation for pasture-based dairy cattle. Applied Animal Behaviour Science, 201, 2018, 2530. doi: 10.1016/j.applanim.2017.12.014 
